\title{
SKIN MOULTING OF INDIAN ROCK PYTHON PYTHON MOLURUS IN CAPTIVITY
}

\section{Raju Vyas}

Sayaji Baug Zoo, Vadodara, Gujarat 390018, India

\section{Introduction}

The skin of a snake is composed of three layers as in other vertebrates. The innermost layer is soft and fibrous, the inner layer dermis contains pigment cells and outer layer is of keratin known as epidermis. New epidermis grows beneath the old, and after it is fully formed, the snake loses the old outer skin. This process is known as ecdysis or sloughing or moulting. The period or interval between two moults varies according to species, age, state of health, food intake and environmental condition.

Stidworthy (1972) describes moulting of snakes in general. Very little is known on the moulting of Indian serpentes. Some information on the moulting of Python reticulatus and $P$. molurus (Biswas \& Acharjyo, 1976 \& 1977; Rathinasabapathy \& Kalaiarasan, 1995), Ophiophagus hannah (Acharjyo et. al., 1978; Acharjyo \& Murthy, 1983) and Vipera russeli (Naulleau \& Brule, 1989; Paulraj \& Naidu, 1987) are available. The present study was carried out from July 1991 to August 1994, at Sayaji Baug Zoo, Vadodara, Gujarat, western India to find out patterns and factors responsible for moulting.

\section{Materials and Methods}

Six newly zoo born pythons, $P$. m. molurus were studied (2 male: 4 female; $x=$ total body length $60.1 \mathrm{~cm}$. and weight 127.1g). Each snake was individually indentified based on natural blotch pattern and numbered as PI, P2 ..... P6. All specimens were maintanined separately in $75 \times 75 \times 65 \mathrm{~cm}$. glass-fronted wooden cages and data on moulting date, behaviour, growth, weight, ambient temperature and humidity were recorded. Food was offered at intervals of four to six days during warmer months (March-Oct.), and 15-20 days during colder months (Nov.-Feb.).

\section{Results}

In total 95 moults were recorded in six pythons from birth to three years. Each )ython on an average moulted 5.27 times per year. The moulting iates and inter moulting days are given in Table 1.

\section{Moulting}

The moulting process could be divided into three phases. It takes about 1-3 days for moulting to get completed. Time taken for moulting increased with the age of the snake.

Phase I: Snake becomes inactive and dull, remains in the hide in coiled position. The skin luster disappears and body colour becomes dark. It is very difficult to know when Phase I begins by just observation. However, one gets an idea that the process would have begun 3 to 24 hours before Phase II.

Phase II: After Phase I (period of 3-24 hours), the body colour of the snake changes to milky white, including the eyes caps. This phase could be observed up to 8-24 hours. The snake's body colour again changes from milky white to dark shade, as earlier.

Phase III: The snake's body colour in dark shade remains for 2 to 48 hours. Soon the snake. becomes active and starts crawling and rubbing the body with objects, removing the old epidermis from lip region. After the completion of moulting, the snake becomes active and is ready for feeding. 
Table 1. Date of moult and inter-moulting days (IMD) observed in each individual specimen of the Indian Rock Python.

\begin{tabular}{|c|c|c|c|c|c|c|c|c|c|c|c|c|}
\hline \multirow[t]{2}{*}{$\mathrm{No}^{*}$} & \multicolumn{2}{|l|}{ Python 1} & \multicolumn{2}{|l|}{ Python 2} & \multicolumn{2}{|l|}{ Python 3} & \multicolumn{2}{|l|}{ Python 4} & \multicolumn{2}{|l|}{ Python 5} & \multicolumn{2}{|l|}{ Python 6} \\
\hline & $\begin{array}{l}\text { Female } \\
\text { Date of } \\
\text { moult }\end{array}$ & IMD & $\begin{array}{l}\text { Female } \\
\text { Date of } \\
\text { moult }\end{array}$ & IMD & $\begin{array}{l}\text { Female } \\
\text { Date of } \\
\text { moult }\end{array}$ & IMD & $\begin{array}{l}\text { Female } \\
\text { Date of } \\
\text { moult }\end{array}$ & IMD & $\begin{array}{l}\text { Male } \\
\text { Date of } \\
\text { moult }\end{array}$ & IMD & $\begin{array}{l}\text { Male } \\
\text { Date of } \\
\text { moult }\end{array}$ & IMD \\
\hline 0 & 15.vii.91 & 0 & 15.vii.91 & 0 & 15.vii.91 & 0 & 15.vii.91 & 0 & 15.vii.91 & 0 & 15.vii.91 & 0 \\
\hline 1 & 17.vii.91 & 2 & 19.vii.91 & 4 & 22.vii.91 & 7 & 20.vii.91 & 5 & 17.vii.91 & 2 & 17.vii.91 & 2 \\
\hline 2 & 24.viii.91 & 38 & $12 \times .91$ & 85 & $13 \times .91$ & 83 & 18.x.91 & 90 & $15 \times 91$ & 90 & 12.ix.91 & 57 \\
\hline 3 & 26.ix.91 & 33 & 07.i.92 & 87 & 26.iii.92 & 165 & 11.iv.92 & 176 & 18.iii.92 & 155 & 05.xi.91 & 54 \\
\hline 4 & $25 \times .91$ & 29 & 10.iv.92 & 94 & 28.v.92 & 63 & 07.vi.92 & 57 & 12.v.92 & 55 & 07.iii.92 & 123 \\
\hline 5 & 18.iv.92 & 176 & 03.vi.92 & 54 & 15.viii.92 & 79 & 24.vii.92 & 47 & 30.vi.92 & 49 & 24.iv.92 & 47 \\
\hline 6 & 08.vi.92 & 51 & 14.vii.92 & 20 & 07.x.92 & 53 & 22.x.92 & 60 & 16.viii.92 & 47 & 15.vi.92 & 53 \\
\hline 7 & 30.vii.92 & 52 & 18.viii.92 & 35 & 28.xi.92 & 52 & 13.xi.92 & 52 & 08.x.92 & 53 & 10.viii.92 & 56 \\
\hline 8 & 08.x.92 & 70 & 13.xi.92 & 87 & 30.iv.93 & 153 & 17.iv.93 & 155 & 12.iii.93 & 155 & 10.ix.92 & 31 \\
\hline 9 & 12.xii.92 & 65 & 01.i.93 & 49 & 08.vi.93 & 39 & 01.vi.93 & 45 & 29.iv.93 & 48 & 12.xii.92 & 93 \\
\hline 10 & 24.iv.93 & 137 & 18.v.93 & 138 & 12.vii.93 & 34 & 05.vii.93 & 34 & 09.vi.93 & 41 & 17.iv.93 & 126 \\
\hline 11 & 31.v.93 & 37 & 28.vi.93 & 39 & 01.ix.93 & 52 & $23 \times .93$ & 110 & 16.vii.93 & 37 & 26.v.93 & 39 \\
\hline 12 & 02.vii.93 & 32 & 18.vii.93 & 20 & 24.x.93 & 53 & 30.iii.94 & 158 & 29.ix.93 & 75 & 28.vi.93 & 33 \\
\hline 13 & 07.ix.93 & 67 & 16.ix.93 & 60 & 09.iv.94 & 193 & 17.vi.94 & 79 & 19.xi.93 & 51 & 08.viii.93 & 41 \\
\hline 14 & $28 . x .93$ & 51 & $24 \times .93$ & 38 & 11.vi.94 & 63 & 21.viii.94 & 65 & 01.iii.94 & 102 & $07 . x .93$ & 60 \\
\hline 15 & 23.iii.93 & 146 & 19.iii.94 & 145 & & & & & 28.vi.94 & 119 & 28.iii.94 & 172 \\
\hline 16 & 01.vi.94 & 71 & 08.v.94 & 50 & & & & & 14.vii.94 & 16 & 12.v.94 & 45 \\
\hline 17 & 25.vii.94 & 54 & 16.vi.94 & 42 & & & & & & & 20.vi.94 & 39 \\
\hline
\end{tabular}

* according to date of birth

Inter-moulting period

The period between date of hatching and first moulting or two consecutive moulting is considered inter-moulting period. Shorter inter-moulting period was observed only during first moult in all pythons. The shortest inter-moulting period recorded was two days which was observed in P1, P5 and P6, during first moult and longer inter-moulting period of 193 days was recorded in $\mathrm{P} 3$, at age three (Table 1). The average inter-moulting period showed an increase with age in all specimens, except in $\mathrm{P} 3$ and P4. Average inter-moulting period decreased during second year (age two) and then it increased. The average inter-moulting period of all the six pythons were: first year 64.74 days and $65.37,81.77$ days during second and third years respectively (Table 2).

\section{Frequency of moulting}

Moulting in python was recorded in all months of the year, except February. The highest of 16 moults were observed in June and July and lowest of two moults were recorded in December and January. Also, the highest number of average moults (3.5) recorded was in Summer (March to June), followed by 3.14 moults in monsoon (July to October) and 0.75 moults in winter (November to February) period (Fig. 1). The annual frequency of moulting noted in the species is six times at first year, 5.3 and 4.5 times at second and third years respectively.

\section{Temperature and moult}

The frequency of moult and the average minimum and maximum temperature shows a correlation. The temperature drops gradually from July to January and it rises during February to May. The number of moults in the species followed the same trend, maximum 16 moults recorded in July and it decreased to two moults in December and January and again increased (Fig. 2). Moreover, average monthly temperature difference between 


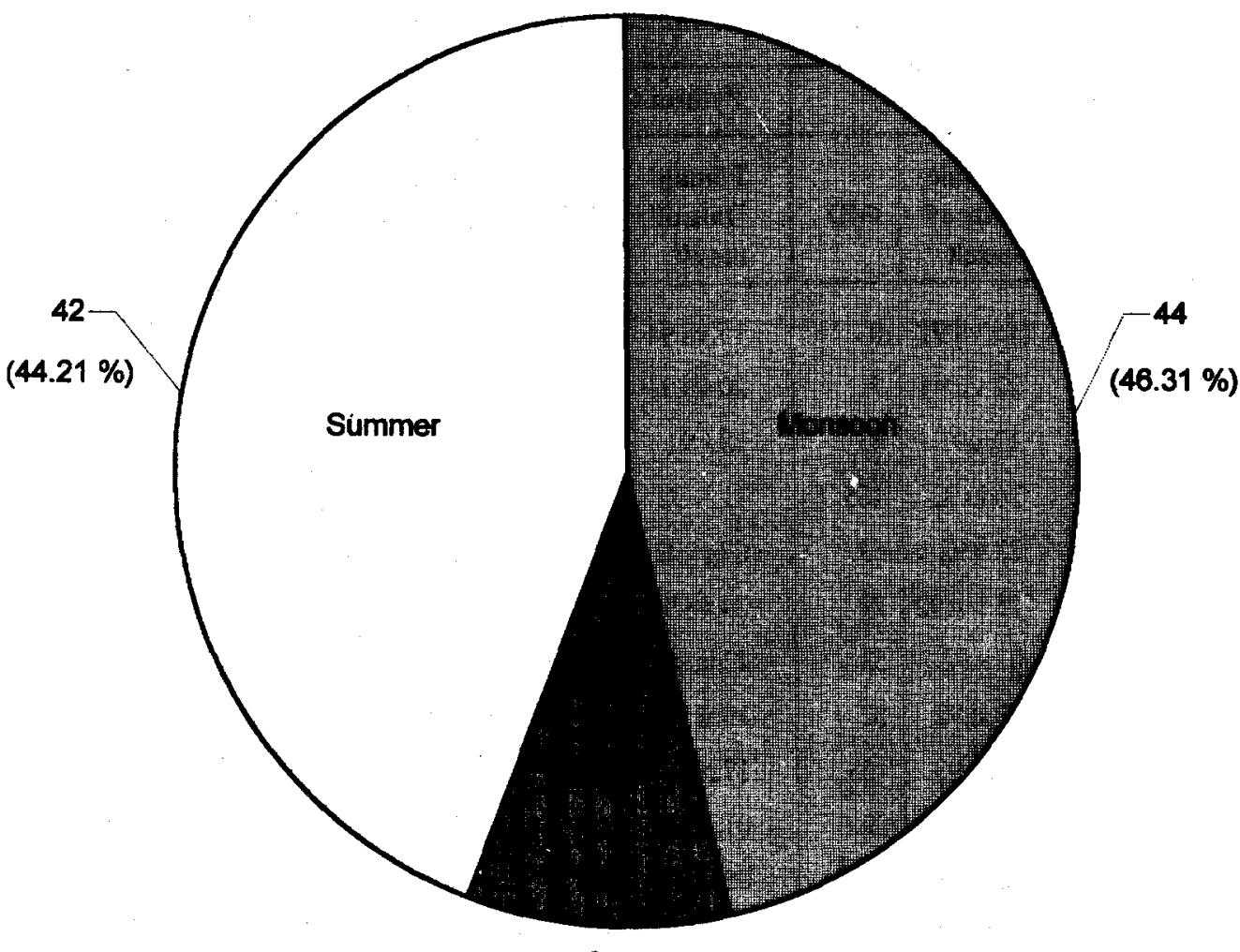

9

(9.47\%)
Figure 1. Python moulting in various seasons.

Table 2. Year-wise moult data of Indian Rock Python in captivity.

\begin{tabular}{|c|c|c|c|c|c|}
\hline \multirow{2}{*}{$\begin{array}{l}\text { Snake } \\
\text { No. } \\
\text { Sex }\end{array}$} & \multirow[t]{2}{*}{ Description } & \multicolumn{4}{|c|}{ Year } \\
\hline & & 1991-92 & $1992-93$ & 1993-94 & $\begin{array}{l}X \text { (average of } \\
\text { three years) }\end{array}$ \\
\hline $\begin{array}{l}\text { P1 } \\
\text { Female }\end{array}$ & $\begin{array}{l}\text { Moult per year } \\
\text { Average inter-moulting days }\end{array}$ & $\begin{array}{l}7 \\
54.42(2-176)\end{array}$ & $\begin{array}{l}5 \\
68.20(32-137)\end{array}$ & $\begin{array}{l}6 \\
77.80(51-146)\end{array}$ & $\begin{array}{l}5.6 \\
66.80(28-153)\end{array}$ \\
\hline $\begin{array}{l}\text { P2 } \\
\text { Female }\end{array}$ & $\begin{array}{l}\text { Moult per year } \\
\text { Average inter-moulting days }\end{array}$ & $\begin{array}{l}6 \\
57.33(4-94)\end{array}$ & $\begin{array}{l}6 \\
61.33(20-138)\end{array}$ & $\begin{array}{l}5 \\
67.00(38-145)\end{array}$ & $\begin{array}{l}5.6 \\
61.88(20-125)\end{array}$ \\
\hline $\begin{array}{l}\text { P3 } \\
\text { Female }\end{array}$ & $\begin{array}{l}\text { Moult per year } \\
\text { Average inter-moulting days }\end{array}$ & $\begin{array}{l}5 \\
79.40(7-165)\end{array}$ & $\begin{array}{l}5 \\
66.20(34-153)\end{array}$ & $\begin{array}{l}4 \\
91.25(52-193)\end{array}$ & $\begin{array}{l}4.6 \\
78.95(31-170)\end{array}$ \\
\hline $\begin{array}{l}\text { P4 } \\
\text { Female }\end{array}$ & $\begin{array}{l}\text { Moult per year } \\
\text { Average inter-moulting days }\end{array}$ & $\begin{array}{l}5 \\
75.00(5-176)\end{array}$ & $\begin{array}{l}5 \\
69.00(37-155)\end{array}$ & $\begin{array}{l}4 \\
103.00(65-110)\end{array}$ & $\begin{array}{l}4.6 \\
82.40(34-147)\end{array}$ \\
\hline $\begin{array}{l}\text { P5 } \\
\text { male }\end{array}$ & $\begin{array}{l}\text { Moult per year } \\
\text { Average inter-moulting days }\end{array}$ & $\begin{array}{l}6 \\
66.33(2-155)\end{array}$ & $\begin{array}{l}5 \\
66.80(37-155)\end{array}$ & $\begin{array}{l}5 \\
72.60(16-102)\end{array}$ & $\begin{array}{l}5.3 \\
68.57(18-137)\end{array}$ \\
\hline $\begin{array}{l}\text { P6 } \\
\text { male }\end{array}$ & $\begin{array}{l}\text { Moult per year } \\
\text { Average inter-moulting days }\end{array}$ & $\begin{array}{l}7 \\
\cdot 56.00(2-123)\end{array}$ & $\begin{array}{l}6 \\
60.50(31-126)\end{array}$ & $\begin{array}{l}4 \\
79.00(39-172)\end{array}$ & $\begin{array}{l}5.6 \\
65.16(24-140)\end{array}$ \\
\hline $\begin{array}{l}\text { Px } \\
\text { Total }\end{array}$ & $\begin{array}{l}\text { Moult per year } \\
\text { Average inter-moulting days }\end{array}$ & $\begin{array}{l}6.00 \\
64.74 \\
(3.6-148.1)\end{array}$ & $\begin{array}{l}5.38 \\
65.37 \\
(31.3-144.0)\end{array}$ & $\begin{array}{l}4.50 \\
81.77 \\
(43.5-144.6)\end{array}$ & $\begin{array}{l}5.27 \\
70.27 \\
(26.1-145.6)\end{array}$ \\
\hline
\end{tabular}

Numbers in parenthesis is range. 


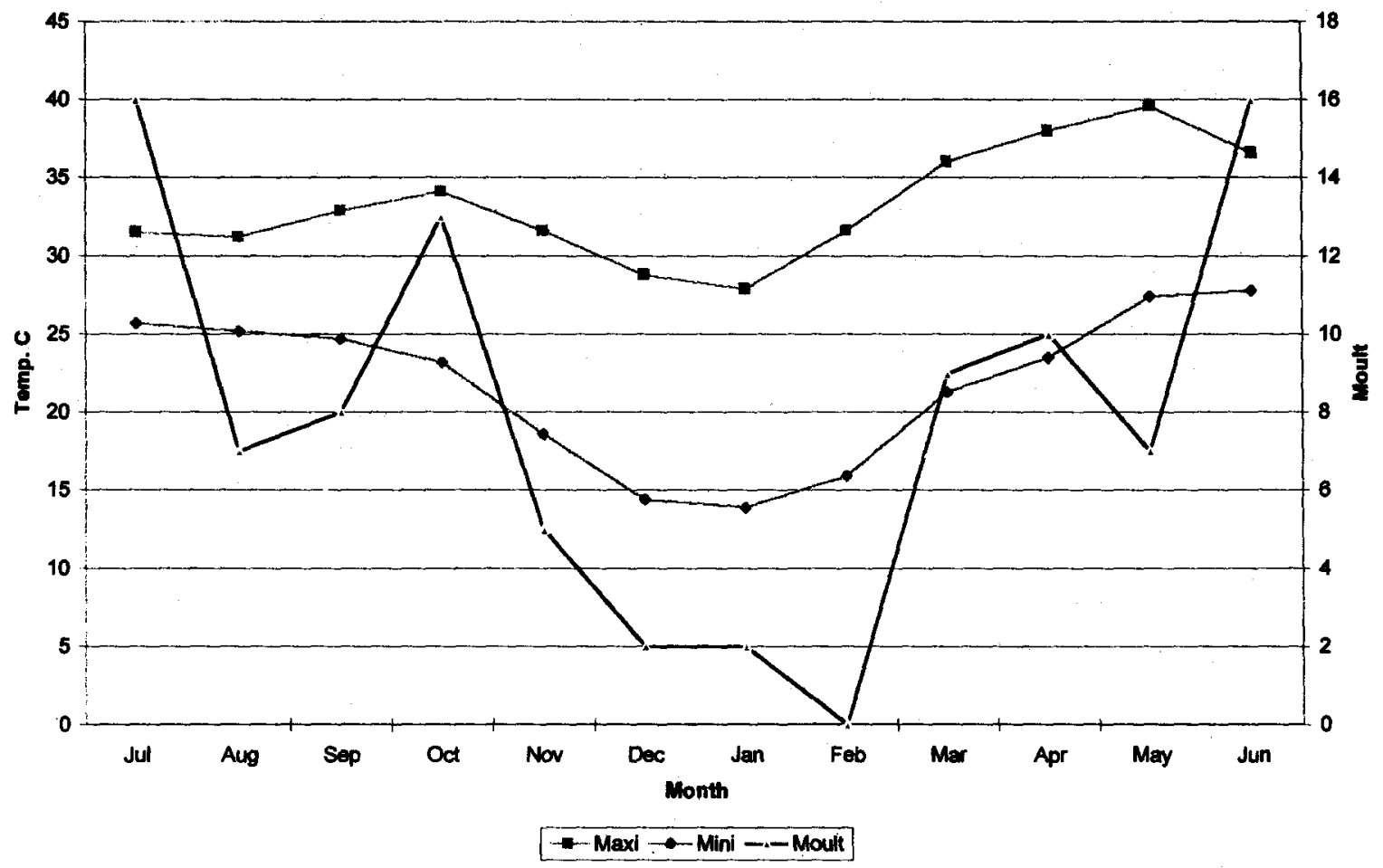

Figure 2. Relationship of Python moulting and temperature

day and night also showed a strong correlation with the total numbers of moults in each month. Temperature difference between day and night increased with the decrease of moulting frequency and as temperature difference between day and night decreased, number of moults also increased (Table 3). Data of relative temperature and humidity and moult in each month indicates that higher number of moults from 16-7 was recorded during temperatures $24^{\circ}-34^{\circ} \mathrm{C}$ and low number of moults (5-0) was observed during temperatures $20^{\circ}-25^{\circ} \mathrm{C}$. A temperature range of $25^{\circ}-34^{\circ} \mathrm{C}$ appear to be the most preferable zone to the species, with relative humidity having no effect on the moulting (Table 3). Every moult was found near the water tank, except in monsoon, this suggests that humidity is also required in final stage of skin shedding.

\section{Moult and time}

Final skin shedding was observed in all parts of the day, except during noon during both winter and summer. Higher numbers of 55 moults $(57.89 \%)$ at night and lower of 40 moults $(41.05 \%)$ at daytime were recorded during the study (Figure 3 ).

\section{Moult and growth}

Each python on an average moulted 15.8 times with total body length reaching $199.5 \mathrm{~cm}$ and body weight reaching $3.6 \mathrm{~kg}$ at the end of three years. Individual growth of male and female python and total numbers of moult showed a leaner relationship. Moreover, sexual maturity in $P$. molurus is related to size and not age, as specimens with higher moulting frequency attain maturity earlier than specimens with lower moulting frequency (Vyas, 1998).

\section{Discussion}

P. molurus moulted 5.27 times per year with average moulting interval of 70.62 (range: 2 to 193) days. Frequency of moult decreased with increase in age of the snake. This supports the study of Naullean and Brule (1989) on Vipera russeli. After adulthood, the growth rate of the snake slows and annual moult rate also decreases. The inter-moulting period of 2 to 193 days does not match with previous record of 31-128 days (Biswas \& Acharjyo, 1976). This could be due to different age group of snakes and environmental conditions. The data of moult in each month and temperature shows a strong correlation, supporting the observation of Naullean and Brule (1989) in Vipera russeli that the process of renewing the epidermis is influenced by temperature than by other factors. During the present study, I did not observe any difference in moulting pattern of male and female. All the snakss studied were immature and the effect perhaps comes into play after maturity.

More numbers of final moults were observed during night than during day. Present study showed that moulting frequency is related to growth. This indicates that keeping records of moulting is also helpful in captive management of the species. I have observed that unwell snakes are unable to cast off the moult 


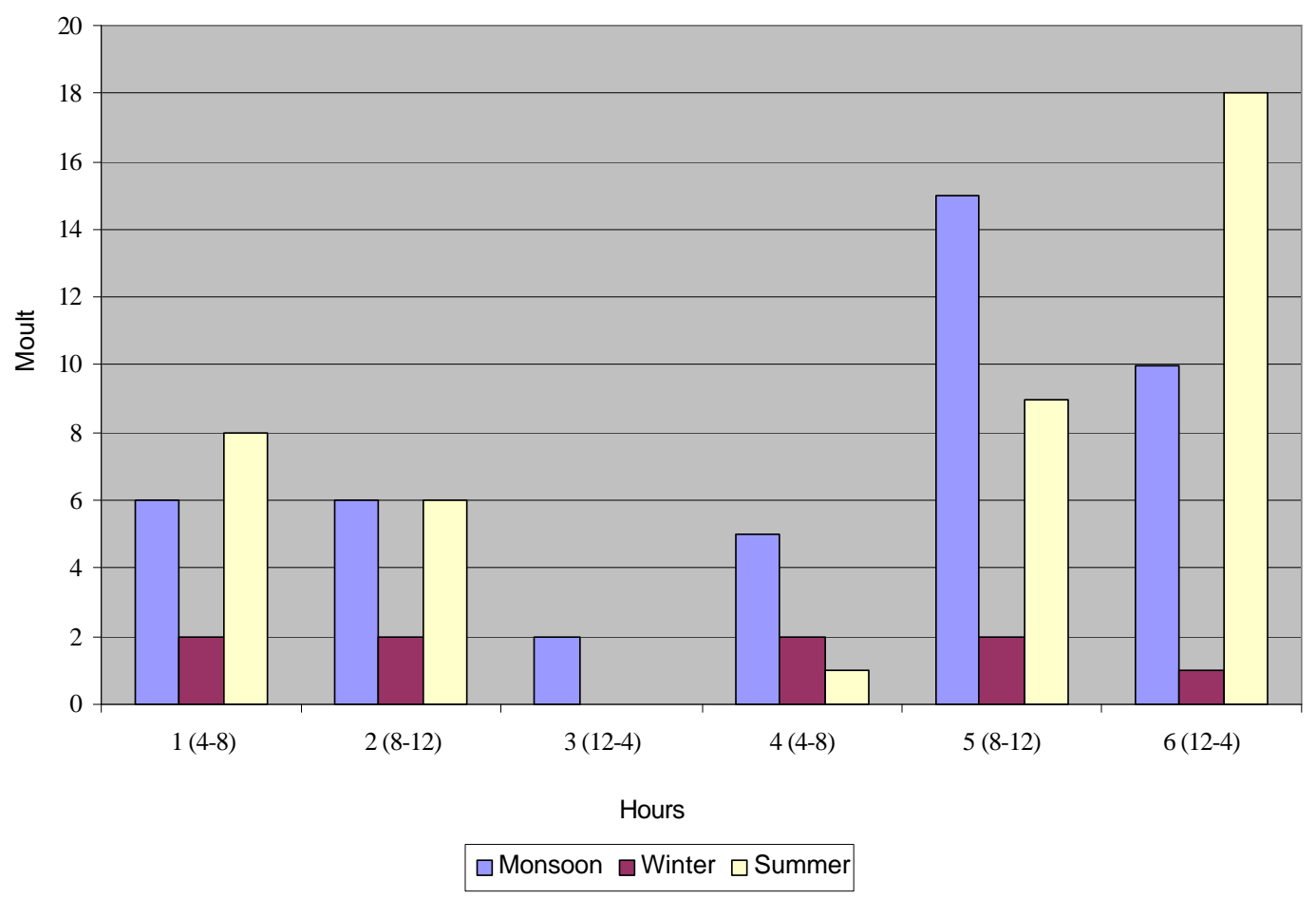

Figure 3. Python moulting pattern in various hours of the day during three sessions

Table 3. Relationship between Indian Rock Python moulting and environmental parameters (temperature in centigrade).

\begin{tabular}{lllllllllllll}
\hline & Jul & Aug & Sep & Oct & Nov & Dec & Jan & Feb & Mar & Apr & May & Jun \\
\hline $\begin{array}{l}\text { Mean Relative Temperature } \\
\text { Mean Temperature Difference }\end{array}$ & 28.6 & 28.2 & 28.8 & 28.8 & 25.1 & 21.6 & 20.9 & 23.4 & 28.6 & 30.7 & 33.5 & 32.2 \\
between day and night & & & & & & & & & & & & \\
Mean Relative Humidity & 5.8 & 5.9 & 8.2 & 10.9 & 13.0 & 14.4 & 13.9 & 16.4 & 14.6 & 14.4 & 12.2 & 8.8 \\
Moult in each month & 86.2 & 84.4 & 77.0 & 67.9 & 55.3 & 57.1 & 56.9 & 48.1 & 43.1 & 45.5 & 54.1 & 65.7 \\
\hline
\end{tabular}

intact, so also the healthy ones. Pieces of the epidermis remain on the body of the snake, especially in vertebral, eyecap, and tail regions. The eye cap problem in the captive snake is due to unnatural or unsuitable housing condition (Gowda, 1963; Acharjyo et.al., 1978, Millichamp, 1986).

\section{Acknowledgement}

I thank V.A. Jadeja, Curator, Sayaji Baug Zoo, Vadodara for providing facilities, M.A. Mehta for reading earlier draft of manuscript. Dr. S. Bhupathy and Dr. L.N. Acharjyo for comments and suggestions on the manuscript.

\section{References}

Acharjyo, L.N. and T.S.N. Murthy (1983). Studies on the King Cobras of Orissa, India. The Snake. 15: 22-31.

Acharjyo, L.N., S. Mohapatra and B. Mishra (1978). On skin sloughing of King Cobras. Ophiophagus hannah (Cantor) in captivity. J Bombay nat. Hist. Soc. 75(1): 234-236.

Biswas, S.and L.N. Acharjyo (1976). Notes on the skin sloughing of Reticulated Python in captivity. J Bombay nat. Hist. Soc. 73:224. Biswas, S. and L.N. Acharjyo (1977). Notes on ecology and biology of some reptiles occurring in and around Nandankanan Biological Park, Orissa. Rec. Zool. Surv. India. 73: 95-109.

Gowda, C.D.K. (1983). Rearing King Cobras in captivity. The Hindu, Sunday. July 21st 1963.

Paulraj, S.and S.S. Naidu (1987). Sloughing and feeding in captive 
young Russel's Viper (Vipera russelli). Animal Keepers Forum. $212-$ 213.

Millichamp, N.J. (1986). Medical aspects of disease in reptile collections. In. The care and breeding of captive reptiles. British Herpetological Society, London. Townson, S., N.J.Millichamp, D.G.D. Lucas and A.J. Millwood (Ed.): 86-98.

Naulleau, G. and V.D. Brule(1989). Feeding, growth, moult and venon production in the Russell's Viper, Vipera russelli. Int. Zoo. Yb.
28: 163-172.

Rathinasabapathy, B. and V. Kalaiarasan (1995). Observation on sloughing in Reticulated Python (P. reticulatus). Animal Keepers Forum. 22(6): 223-225.

Sidworthy, J. (1972). Snakes of the world. Bantom Books, New York. $159 \mathrm{pp}$.

Vyas, R. (1998). Note on growth and maturity in the Indian Rock Python (Python molurus molurus). Hamadryad. 23(1): 69-71.

\title{
SPOTTED DEER (AXIS AXIS ERXLEBEN) HERD IN OSMANIA UNIVERSITY DEER PARK, HYDERABAD
}

\author{
C. Srinivasulu ${ }^{1}$, V. Nagulu ${ }^{1}$, V.Vasudeva Rao $^{1}$ and Harsha Reddy ${ }^{2}$ \\ 'Wildlife Biology Section, Department of Zoology, Osmania University, Hyderabad, Andhra Pradesh 500007, India. \\ ${ }^{2}$ Research Student, College Year in India Programme, University of Wisconsin, Madison, Wisconsin, USA.
}

\section{Introduction}

The Osmania University Deer Park was established on 30 July 1990 with a breeding group of 10 ( 2 Males and 8 Females) spotted deer (Axis axis Erxleben). Since then the group has bred successfully and the present population consists of about $90+$ animals. Due to habitat constraints the threshold level of the carrying capacity has been reached. To study the herd characteristics and assess the habitat conditions the present team conducted a three-month observation. This report elaborates the findings of these surveys and deals largely with the population status of the herd and management conditions of the park.

\section{Study Area}

Established in the year 1918, Osmania University is the ninth oldest and one of the most prestigious universities of India. Located on the northeastern flank of Hyderabad (circa $24^{\circ} \mathrm{N}$ and $32^{\circ} \mathrm{E}$ ), its campus forms an extensive expanse of about 679 ha. of semi wilderness. The general topography is rocky with altitude ranging between $500-538 \mathrm{~m}$. Of the vast expanse, 400 440 ha. of land is developed as Dalbergia, Eucalyptus and Leucaena plantations under various Urban-Forestry Development Plans. About 12.8 ha. of land is maintáned as University (Landscape) Garden where a variety of vegetation is grown.

Vegetation is represented by more than 900 species, of which the important and dominant ones are Acacia arabica, Acacia nilotica, Azadirachta indica, Bauhinia variegata, Bauhinia vahli, Butea monosperma, Cassia fistula, Cassia auriculata, Casuarina equesitifolia, Annona squamosa, Polyalthia longifolia, Pheltophorum roxburghianum, Dalbergia latifolia, Ficus religiosa, Mangifera indica, Delonix regia, Randia dumetorum, Prosopis juliflora, Erythrina indica, Holoptelia integrifolia, Syzizium cumini, Lawsonia glauca, Terminalia tomentosa, Tamarindus indicus, Thespesia populnea, Pongamia pinnata, Parkinsonia spp., Calophyllum inophyllum, Borassus flabelifer, Phoenix sylvestris, Lantana camara, Zizyphus jujuba and Ziziphus oenoplia.

The Deer Park covers an expanse of about 24 ha. or 60 acres and is located south of the Vice-Chancellor's Lodge (Figure 1). Natural vegetative cover within the Deer Park is rather sparse due to the scrubby nature of the habitat. Chief cover is that of Leucaena leucocephala and Dalbergia sissoo planted under the Energy Plantation Scheme of the University. Principal woody species include Azadirachta indica, Prosopis juliflora, Acacia spp. and Albizzia spp. Undergrowth includes Lantana camara, Calotropis gigantea, Calotropis procera, Zizyphus jujuba, Cassia auriculata, Randia dumetorum, etc. Herbaceous species are sparse and are represented by Achyranthus aspera, Hemidesmus indicus, Tephrosia purpurea, Tribulus terrestris, etc. 